\title{
Correlation of ghrelin and growth hormone secretagogue receptor expression with clinical features in human pituitary adenomas
}

\author{
JUNWEN WANG ${ }^{1}$, SONGBO GUO ${ }^{2}$, LIN HAN ${ }^{2}$, MINGBO FANG $^{1}$, LEI WANG ${ }^{1}$, JÖRG W. BARTSCH ${ }^{3}$ and JUN LI ${ }^{1}$ \\ ${ }^{1}$ Department of Neurosurgery, Wuhan Central Hospital; ${ }^{2}$ Department of Neurosurgery, Tongji Hospital, \\ Tongji Medical College Affiliated to Huazhong University of Science and Technology, Wuhan, \\ Hubei 430014, P.R. China; ${ }^{3}$ Department of Neurosurgery, Marburg University, D-35033 Marburg, Germany
}

Received July 10, 2014; Accepted March 3, 2015

DOI: $10.3892 /$ etm.2015.2341

\begin{abstract}
Ghrelin, as a brain-gut peptide, has growth hormone $(\mathrm{GH})$-releasing and appetite-inducing activities and a widespread tissue distribution. Furthermore, ghrelin is an endogenous ligand of the GH secretagogue receptor (GHSR), and both ghrelin and GHSR are expressed in the pituitary; however, the data regarding the expression of ghrelin and GHSR in pituitary adenomas are divergent and conflicting. In the present study, therefore, the expression of ghrelin and GHSR was examined in the full spectrum of human pituitary adenoma subtypes $(n=34)$ and in normal pituitary tissue $(n=3)$. The mRNA and protein expression levels were quantified using a competitive reverse transcription-polymerase chain reaction and western blotting and the correlation of the results with the clinical parameters was assessed. mRNA and protein expression of ghrelin and GHSR was detected in all samples with the highest mean level in GH adenomas, a moderate level in clinically non-functioning adenomas and the lowest level in adrenocorticotropin adenomas. A significant correlation between the ghrelin and GHSR mRNA expression levels was observed in the GH adenomas $(n=12)(r=0.8435, P=0.0006)$. The ghrelin mRNA expression level in the $\mathrm{GH}$ adenomas correlated positively with the basic serum GH level $(n=12)(r=0.6488$, $\mathrm{P}=0.0225$ ). Furthermore, the mean level of ghrelin mRNA expression was significantly higher in invasive adenomas than in noninvasive adenomas $(\mathrm{P}<0.01)$. Collectively, the results of the study provided evidence that ghrelin and GHSR are expressed in the various subtypes of pituitary adenoma, with specific overexpression in GH adenomas. The study suggests that the binding of ghrelin to GHSR promotes the secretion of $\mathrm{GH}$ and plays an important role in the development of $\mathrm{GH}$ adenomas via autocrine and/or paracrine effects.
\end{abstract}

Correspondence to: Dr Jun Li, Department of Neurosurgery, Wuhan Central Hospital, 26 Shengli Road, Wuhan, Hubei 430014, P.R China

E-mail: t0102079@hotmail.com

Key words: ghrelin, growth hormone secretagogue receptor, pituitary adenomas, expression

\section{Introduction}

The secretion of growth hormone $(\mathrm{GH})$ is regulated by a number of hypothalamic, pituitary and circulating factors, and the classic hypothalamo-GH axis includes the GH secretagogues (GHSs) and GH-releasing hormone (GHRH), as well as pituitary GH. It is well established that both GHSs and GHRH can stimulate $\mathrm{GH}$ secretion from the anterior pituitary through different mechanisms (1). GHRH, which is synthesized by neurons in the arcuate nucleus and secreted into the portal vessels, binds to GHRH receptors (GHRH-Rs) in the anterior pituitary, whilst GHS binds to GHS receptors (GHSRs) in the hypothalamus and pituitary. These two receptors belong to the G-protein-coupled receptor family (2). Human GHSR contains two subtypes, type 1a (GHSR-1a) and type 1b (GHSR-1b), with the latter being 77 amino acids shorter than the former. Generally, GHRS-1a binds and responds to GHS, while GHRS-1b is biologically inactive (3).

Ghrelin, a 28-amino acid peptide and an endogenous ligand of GHSR, was originally isolated from the rat stomach (4) and characterized, but both ghrelin and GHSR are expressed in a number of other tissues, including the hypothalamus, where the highest concentration of GHSR has been described (5). GHRH acts to induce the proliferation of somatotroph cells, as well as the synthesis and secretion of GH. GHRH gene expression has been found in normal pituitary and $\mathrm{GH}$-secreting pituitary adenomas; since concurrent GHRH-R expression can also be found in these adenomas, it has been suggested that GHRH may be involved in the neoplastic progression of GH-releasing adenoma cells (6). Ghrelin, by comparison, is believed to induce GH secretion by binding to GHSR, and its expression, along with that of GHSR, can be found in the normal pituitary as well as in various types of pituitary adenomas (7). These results have raised the possibility that ghrelin and GHSR are involved in the neoplastic progression of pituitary adenomas.

Previous studies investigating ghrelin and GHSR expression in pituitary adenomas have produced conflicting results $(3,6,8)$, and data showing the correlation between ghrelin and GHSR expression levels and the clinical features of pituitary adenomas are limited. The aim of the present study, therefore, was to examine the mRNA and protein expression levels of ghrelin and GHSR in a full spectrum of human pituitary adenoma subtypes, as well as normal pituitary tissue, and 
to analyze the correlation between the expression and clinical characteristics in detail.

\section{Materials and methods}

Human pituitary tissues and adenomas. Ethical approval was obtained from the Ethics Committee of Wuhan Central Hospital (Wuhan, China) in accordance with the Declaration of Helsinki, and written informed consent was obtained from each individual patient. A total of 34 patients with pituitary adenomas and a mean age of 39.9 \pm 11.1 years (19 women and 15 men; age range, 17-79 years) were enrolled in this study. Pituitary adenoma tissues were obtained at the time of transsphenoidal surgery. Normal human pituitary tissues $(n=3)$ were also collected at autopsy (4-24-h postmortem) from patients with no evidence of endocrine abnormality. The tumor type was determined according to clinical and biochemical findings and immunochemical data prior to surgery. Specimens included $12 \mathrm{GH}, 7$ prolactin (PRL) hormone, 4 adrenocorticotropin (ACTH), 3 thyroid-stimulating hormone (TSH) and 8 non-functioning (NF) adenomas. Tumor invasiveness was defined on the basis of preoperative radiological investigation using the Knosp classification (9) and was confirmed during surgery. Basic serum GH levels were also examined without any drug treatment prior to surgery. Patient data regarding gender, age, basic serum GH level and tumor type, diameter and invasiveness are summarized in Table I.

RNA preparation and competitive reverse transcription-polymerase chain reaction ( $R T-P C R)$ analysis. Total RNA was extracted from tumor tissue using an SV total RNA isolation kit (Promega Corp., Southampton, UK) with a deoxyribonuclease treatment step. The quantification of the RNAs was performed by Cecil CE5501 computing double-beam ultraviolet spectrophotometry (Cecil Instruments Ltd., Cambridge, UK). cDNA was generated from each sample using Moloney murine leukemia virus reverse transcriptase (M-MLVRT) (Life Technologies, Paisley, UK). Each reaction mixture contained $10 \mu 15 \mathrm{X}$ first strand buffer, $2 \mu 10.1 \mathrm{M}$ dithiothreitol (DTT) (buffer and DTT supplied with M-MLVRT), $2.5 \mu \mathrm{l}$ $20 \mu \mathrm{M}$ deoxynucleotide triphosphate (Promega Corp.), $0.25 \mu \mathrm{l}$ $20 \mathrm{mg} / \mathrm{ml}$ random hexamers (Boehriger Mannheim GmbH, Mannheim, Germany), $1 \mu 1200$ U/ml M-MLVRT, $0.1 \mu 1$ rRNasin $^{\circledR}$ (Promega Corp.), RNA stock solution containing $5 \mu \mathrm{g}$ RNA (heated to $65^{\circ} \mathrm{C}$ for $10 \mathrm{~min}$ ) and water to a final volume of $50 \mu \mathrm{l}$. The program for the thermal cycler (Hybaid OmniGene, Teddington, UK) was $25^{\circ} \mathrm{C}$ for $10 \mathrm{~min}, 37^{\circ} \mathrm{C}$ for $60 \mathrm{~min}$ and $92^{\circ} \mathrm{C}$ for $10 \mathrm{~min}$. The integrity of the mRNA from each specimen was verified by RT-PCR for the reference gene $\beta$-actin. RT-PCR primers and probes were designed for human ghrelin, GHSR and $\beta$-actin using GeneFisher ${ }^{\circledR} 1.3$ software (GeneFisher PCR Subtraction System; Takara Shuzo Co., Ltd., Kyoto, Japan) based on the sequence data of the genes available in GenBank (http://www.ncbi.nlm.nih.gov/genbank/) (Table II). The primers and probes were purchased from Takara Shuzo Co., Ltd. For PCR, $5 \mu 1 \mathrm{cDNA}, 2 \mu 110 \mathrm{mM}$ human ghrelin primers, $0.6 \mu 110 \mathrm{mM} \beta$-actin primers, $25 \mu \mathrm{l}$ 2X Fast PCR Master Mix (Takara Shuzo Co., Ltd.) and water were used in a 50- $\mu 1$ reaction volume. Thirty cycles were performed at $94^{\circ} \mathrm{C}$ for $1 \mathrm{~min}, 55^{\circ} \mathrm{C}$ for $45 \mathrm{sec}$ and $72^{\circ} \mathrm{C}$ for
$45 \mathrm{sec}$, following a denaturing cycle of $95^{\circ} \mathrm{C}$ for $5 \mathrm{~min}$. A final extension cycle of $5 \mathrm{~min}$ at $72^{\circ} \mathrm{C}$ was then conducted. All amplifications were run on ethidium bromide-stained $2 \%$ agarose gels and the results were documented using a UV PCR cabinet and workstation (UVP Inc., Upland, CA, USA).

Protein extraction and western blotting. Human pituitary and adenoma tissue samples $(0.05 \mathrm{~g} / \mathrm{sample})$ were stored at $-80^{\circ} \mathrm{C}$ and homogenized in $1 \mathrm{ml} \mathrm{TRIzol}{ }^{\circledR}$ reagent (Invitrogen Life Technologies, Carlsbad, CA, USA), and the total protein was isolated in accordance with the manufacturer's instructions. Protein concentration assessment was performed using a bicinchoninic acid assay (Beyotime Institute of Biotechnology, Beijing, China). Equal quantities of sample extract were separated using $10 \%$ SDS-PAGE, prior to the transferal of the proteins onto nitrocellulose membranes. The membranes were blocked in 5\% non-fat, dried milk in $50 \mathrm{mM}$ Tris ( $\mathrm{pH} 7.5)$, $0.15 \mathrm{M} \mathrm{NaCl}$ and $0.05 \%$ Tween-20 at room temperature for $1 \mathrm{~h}$ and then incubated with primary antibodies at $37^{\circ} \mathrm{C}$ for $2 \mathrm{~h}$ or $4^{\circ} \mathrm{C}$ overnight, depending on the manufacturers' instructions. The primary antibodies were as follows: goat polyclonal for ghrelin (1:1,000; cat\# sc-10368; Santa Cruz Biotechnology, Inc., Santa Cruz, CA, USA), goat polyclonal for GHSR (1:1,000; cat\# sc-10362; Santa Cruz Biotechnology, Inc.) and goat polyclonal for $\beta$-tubulin (1:1,000; cat\# sc-31779; Santa Cruz Biotechnology, Inc.). Following incubation with the primary antibodies, the blots were washed and incubated with a donkey anti-goat IgG horseradish peroxidase-conjugated secondary antibody (1:1,000; cat\# sc-2020; Santa Cruz Biotechnology, Inc.) at $37^{\circ} \mathrm{C}$ for $1 \mathrm{~h}$. The peroxidase activity on the blots was determined using SuperSignal chemiluminescent substrate (Pierce Co., Rockford, IL, USA).

Statistical analysis. Data are expressed as the mean \pm standard deviation and were analyzed using the SPSS 10.0 software package (SPSS, Inc., Chicago, IL, USA). Analyses of variance with a protected t-test were used for intergroup comparisons, and correlations were analyzed using linear regression analysis. $\mathrm{P}<0.05$ was considered to indicate a statistically significant difference.

\section{Results}

Quantification of ghrelin and GHSR mRNA expression in human pituitary tissues and adenomas. Ghrelin and GHSR mRNA expression was detected in all human pituitary and adenomas samples. The highest mean levels of the two mRNAs were found in the $\mathrm{GH}$ adenomas, while a moderate level was found in NF adenomas. ACTH adenomas exhibited the lowest level of ghrelin and GHSR mRNA expression. The mRNA expression levels in the GH and NF adenomas were significantly higher than those in the normal human pituitary (Fig. 1). Furthermore, a significant correlation was observed between the expression levels of ghrelin and GHSR mRNA in $\mathrm{GH}$ adenomas $(\mathrm{n}=12)(\mathrm{r}=0.8435, \mathrm{P}=0.0006)$ (Fig. 2).

Quantification of ghrelin and GHSR protein expression in human pituitary tissues and adenomas. The detection of ghrelin and GHSR protein expression was performed by western blotting, and the band intensity was calculated 
Table I. Summary of the clinical and histological characteristics of the patients and adenomas.

\begin{tabular}{|c|c|c|c|c|c|c|}
\hline Case no. & Gender & Age (years) & $\begin{array}{c}\text { Basic serum } \\
\text { GH level }(\mu \mathrm{g} / \mathrm{l})\end{array}$ & $\begin{array}{c}\text { Tumor } \\
\text { diameter }(\mathrm{mm})\end{array}$ & $\begin{array}{l}\text { Immunohistochemical } \\
\text { staining }\end{array}$ & $\begin{array}{l}\text { Invasiveness } \\
\qquad(+/-)\end{array}$ \\
\hline \multicolumn{7}{|c|}{ GH adenomas } \\
\hline 1 & Male & 50 & 15.72 & 17 & GH (2+) PRL (1+) & - \\
\hline 2 & Male & 29 & 101.44 & 14 & GH (3+) PRL (1+) & + \\
\hline 3 & Female & 41 & 145.53 & 26 & GH (3+) PRL (2+) & + \\
\hline 4 & Female & 37 & 12.39 & 12 & $\mathrm{GH}(1+)$ & + \\
\hline 5 & Male & 17 & 141.78 & 17 & GH (3+) PRL (1+) & - \\
\hline 6 & Female & 31 & 64.32 & 44 & GH (2+) PRL (2+) & + \\
\hline 7 & Male & 40 & 57.43 & 25 & GH (2+) PRL (1+) & - \\
\hline 8 & Male & 33 & 241.75 & 28 & GH (3+) PRL (2+) & + \\
\hline 9 & Female & 20 & 201.76 & 18 & GH (2+) PRL (2+) & + \\
\hline 10 & Female & 41 & 34.31 & 16 & GH (2+) PRL (1+) & - \\
\hline 11 & Male & 30 & 110.91 & 23 & GH (2+) PRL (2+) & + \\
\hline 12 & Male & 61 & 89.34 & 19 & $\mathrm{GH}(1+)$ & + \\
\hline \multicolumn{7}{|c|}{ PRL adenomas } \\
\hline 13 & Male & 50 & 5.12 & 12 & PRL (2+) & - \\
\hline 14 & Female & 30 & 1.78 & 21 & PRL (2+) & + \\
\hline 15 & Female & 25 & 0.86 & 12 & PRL (1+) & - \\
\hline 16 & Female & 47 & 1.52 & 38 & PRL (3+) & + \\
\hline 17 & Female & 31 & 0.78 & 11 & PRL (1+) & - \\
\hline 18 & Male & 48 & 2.42 & 21 & PRL (2+) & + \\
\hline 19 & Female & 36 & 1.81 & 23 & PRL (3+) & + \\
\hline \multicolumn{7}{|c|}{ ACTH adenomas } \\
\hline 20 & Female & 37 & 0.45 & 9 & ACTH (2+) & - \\
\hline 21 & Male & 34 & 0.63 & 18 & ACTH (3+) & + \\
\hline 22 & Female & 45 & 1.54 & 15 & ACTH (2+) & - \\
\hline 23 & Female & 17 & 1.62 & 12 & ACTH (2+) & - \\
\hline \multicolumn{7}{|c|}{ TSH adenomas } \\
\hline 24 & Male & 44 & 56.60 & 14 & TSH (2+) & + \\
\hline 25 & Female & 39 & 8.47 & 38 & TSH (3+) & + \\
\hline 26 & Female & 52 & 0.95 & 17 & TSH (2+) & - \\
\hline \multicolumn{7}{|c|}{ NF adenomas } \\
\hline 27 & Female & 56 & 6.32 & 26 & & + \\
\hline 28 & Female & 53 & 1.54 & 33 & & - \\
\hline 29 & Male & 26 & 1.69 & 41 & & - \\
\hline 30 & Male & 41 & 2.13 & 22 & & + \\
\hline 31 & Female & 53 & 1.27 & 25 & & - \\
\hline 32 & Female & 50 & 1.61 & 18 & & - \\
\hline 33 & Male & 79 & 2.83 & 23 & & + \\
\hline 34 & Male & 35 & 0.81 & 28 & & + \\
\hline
\end{tabular}

Staining was graded as -, none; +, weak and/or focal; $2+$, moderate strength and/or majority of cells; or 3+, strong and/or majority of cells. Invasiveness of adenomas was graded as -, Knosp classification 0-1; or +, Knosp classification 2-4 (9). GH, growth hormone; PRL, prolactin; $\mathrm{ACTH}$, adrenocorticotropin; TSH, thyroid-stimulating hormone; NF, non-functioning.

using $\beta$-tubulin as a reference. The results showed that ghrelin and GHSR protein expression correlated with the mRNA expression. The strongest bands were from the $\mathrm{GH}$ adenomas, moderate bands were from the NF adenomas and the weakest bands were from the ACTH adenomas. The protein expression levels in the $\mathrm{GH}$ and NF adenomas were also significantly higher than those in the normal human pituitary (Fig. 3).

Comparison of the ghrelin mRNA expression levels with clinical features in GH adenomas. The present study demonstrated i) specific overexpression of ghrelin and GHSR in GH 
Table II. Primer sequences.

Gene (GenBank accession no.)

Primer sequence $\left(5^{\prime}-3^{\prime}\right)$

Product size (bp)

Ghrelin (BO35700)

Sense: GAGCCCTGAACACCAGAGAG

Antisense: TCCCAGAGGATGTCCTGAAG

GHSR (U60179)

Sense: GATCTGCTCATCTTCCTCTG

105

Antisense: ACTGACGAATTGGAAGAGTT

$\beta$-actin (BF000319)

GHSR, growth hormone secretagogue receptor.

A
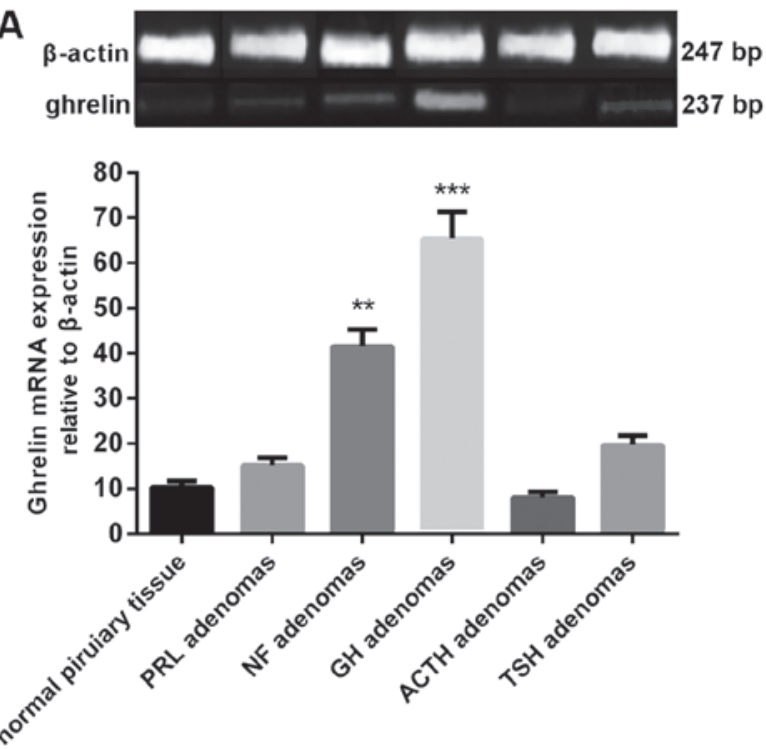

B
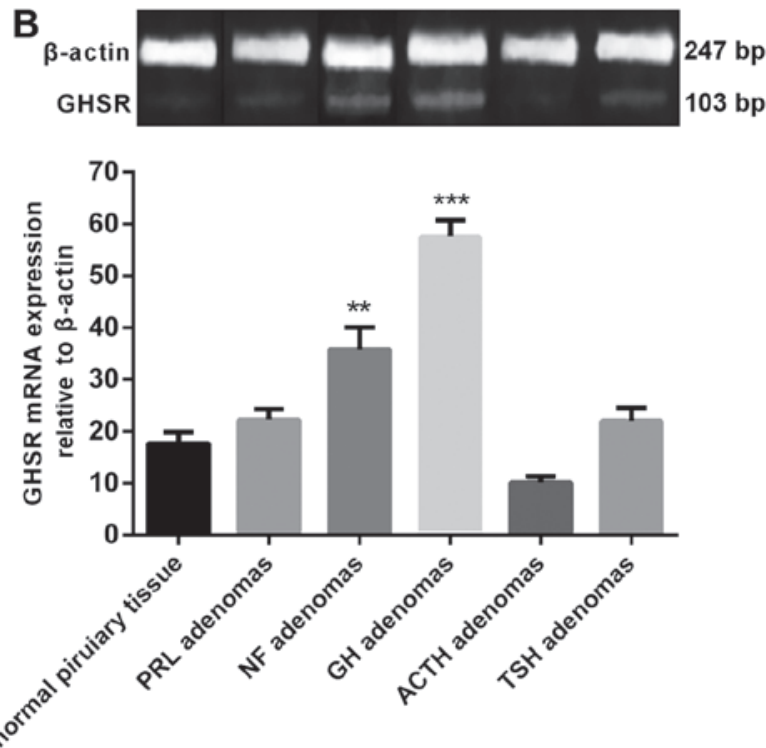

Figure 1. Reverse transcription-polymerase chain reaction analysis showed that (A) ghrelin and (B) GHSR mRNA expression was present in all human pituitary and adenoma samples, with the highest mean level in GH adenomas, a moderate level in NF adenomas and the lowest level in ACTH adenomas. ${ }^{* *} \mathrm{P}<0.01$ and ${ }^{* * *} \mathrm{P}<0.001$ vs. normal pituitary tissue. GH, growth hormone; GHSR, GH secretagogue receptor; PRL, prolactin; NF, non-functioning; ACTH, adrenocorticotropin; TSH, thyroid-stimulating hormone.

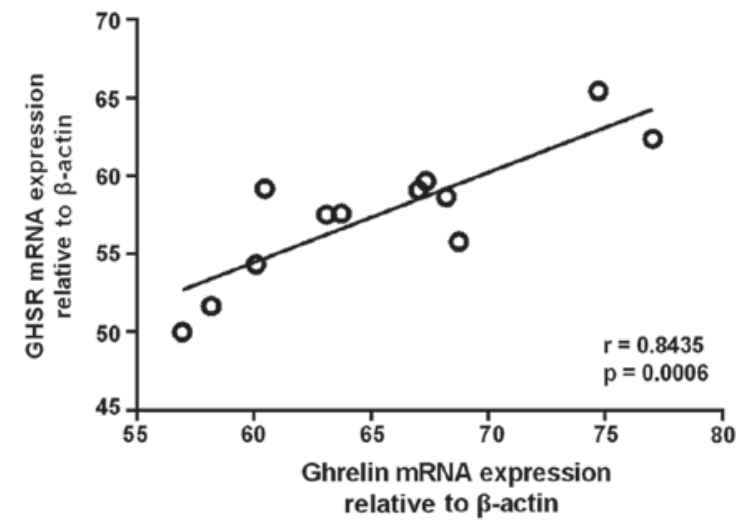

Figure 2. Linear regression analysis revealed a significant correlation between the expression levels of ghrelin and GHSR mRNA in GH adenomas. $\mathrm{GH}$, growth hormone; GHSR, GH secretagogue receptor.

adenomas, and ii) a significant correlation between ghrelin and GHSR mRNA expression levels. The next part of the experiment therefore focused on $\mathrm{GH}$ adenomas and compared the ghrelin mRNA expression levels with various clinical features, including tumor diameter, tumor invasiveness and basic serum $\mathrm{GH}$ level. It was found that ghrelin mRNA expression levels in the GH adenomas correlated positively with basic serum GH levels $(n=12)(r=0.6488, P=0.0225)$, but negatively with tumor diameter $(\mathrm{n}=12)(\mathrm{r}=-0.1691, \mathrm{P}=0.5993)$ (Fig. 4). In invasive $\mathrm{GH}$ adenomas, the ghrelin mRNA expression levels were significantly higher than those in noninvasive $\mathrm{GH}$ adenomas $(\mathrm{P}<0.01)$ (Fig. 5).

\section{Discussion}

Ghrelin is a 28 -amino acid peptide that was originally isolated from the stomach (4) but has also been found in other tissues, including the hypothalamic arcuate nucleus (10). As the natural ligand of GHSR, ghrelin specifically activates the GHSR and stimulates GH release in vitro while having no direct effect on other hormone subtypes, such as ACTH, PRL and TSH $(11,12)$. Ghrelin has also been demonstrated to stimulate $\mathrm{GH}$ release in anesthetized rats (13). An $n$-octanoyl group on the third 

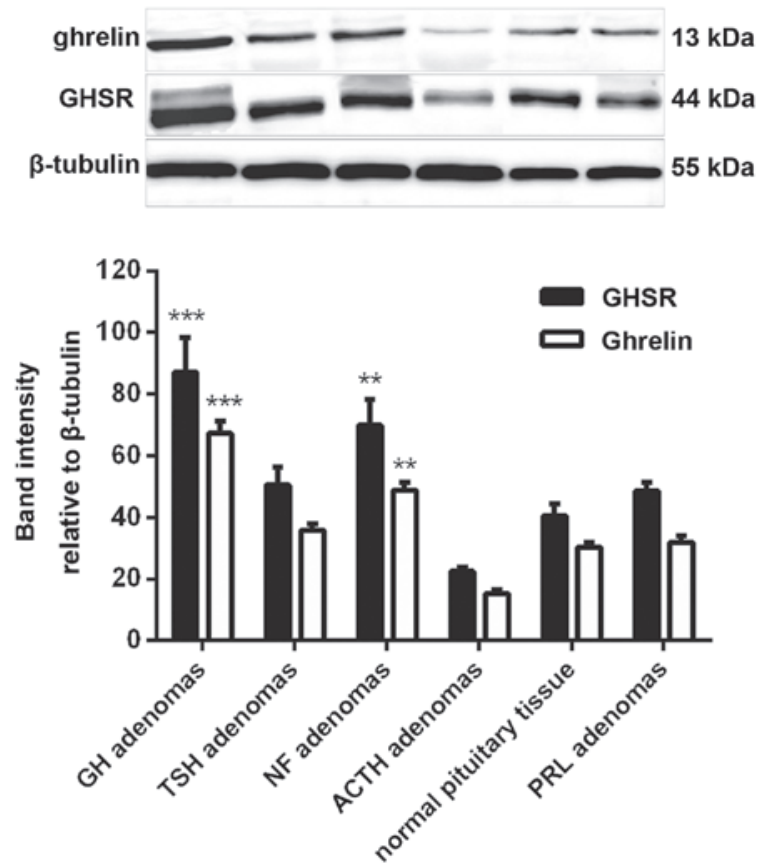

Figure 3. Western blot analysis showed that the ghrelin and GHSR protein expression followed the same pattern, with the highest mean level in $\mathrm{GH}$ adenomas, a moderate level in NF adenomas and the lowest level in ACTH adenomas. ${ }^{* *} \mathrm{P}<0.01$ and ${ }^{* * *} \mathrm{P}<0.001$ vs. normal pituitary tissue. $\mathrm{GH}$, growth hormone; GHSR, GH secretagogue receptor; PRL, prolactin; NF, non-functioning; ACTH, adrenocorticotropin; TSH, thyroid-stimulating hormone.
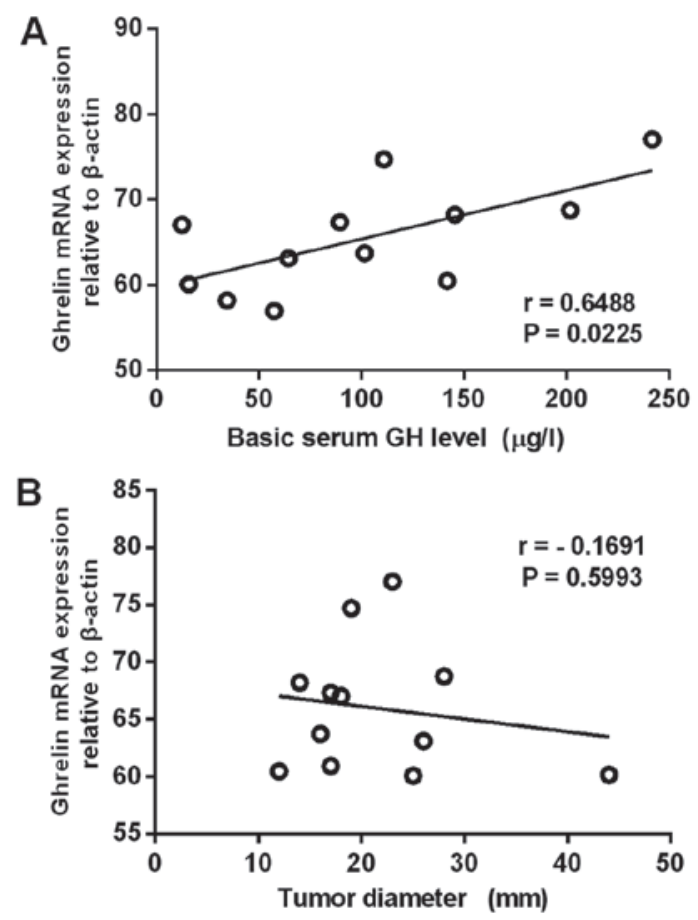

Figure 4. Linear regression analysis revealed that the ghrelin mRNA expression level in $\mathrm{GH}$ adenomas correlated (A) positively with the basic serum $\mathrm{GH}$ level, but (B) negatively with tumor diameter. GH, growth hormone.

amino acid of ghrelin is required for its biological activity, and the protein sequence has been shown to be highly conserved between species, with rat and human ghrelins only differing by two amino acids. Previous in vitro and in vivo studies using

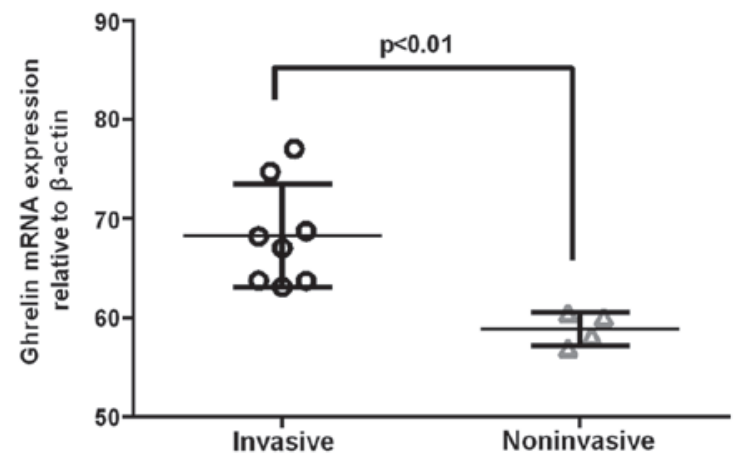

Figure 5. Comparison of ghrelin mRNA expression in invasive $(\mathrm{n}=8)$ and noninvasive ( $\mathrm{n}=4) \mathrm{GH}$ adenomas, shown as individual data points with the mean values given as a horizontal line. Note that the levels of ghrelin mRNA expression are significantly higher in invasive $\mathrm{GH}$ adenomas than those in the noninvasive adenomas $(\mathrm{P}<0.01)$. GH, growth hormone.

synthetic GH secretagogues (GHSs) have suggested that the effects of these GHSs are mediated by the hypothalamus (14-16). GHSs have also been shown to stimulate GH release directly from the isolated rat or human pituitary. Previous studies using RT-PCR, immunohistochemistry and double immunogold electron microscopy have demonstrated the expression of ghrelin and GHSR in various pituitary adenoma subtypes $(3,6,7,8,17,18)$; however, the results have been divergent. Kim et al $(3,8)$ found that ghrelin mRNA was expressed in various pituitary adenoma subtypes, the highest levels of expression being noted in NF adenomas and the lowest in prolactinomas. Skinner et al (6) observed the highest GHSR mRNA expression in GH adenomas and the lowest in ACTH adenomas. No correlation was found, however, between ghrelin or GHSR expression levels and circulating GH levels in any studies $(7,17,18)$.

In the present study, the ghrelin and GHSR expression was assessed at the mRNA and protein levels using RT-PCR and western blotting, respectively. The results showed that ghrelin and GHSR mRNA were expressed in various pituitary adenomas and in the normal pituitary, but that the expression levels varied among different types of adenomas, with the highest level in $\mathrm{GH}$ adenomas, a moderate level in NF adenomas and the lowest level in ACTH adenomas. A significant correlation was found between the expression levels of ghrelin and GHSR mRNA in $\mathrm{GH}$ adenomas. The same pattern was observed in the protein expression levels using western blotting. One notable finding was that the ghrelin mRNA expression levels in the GH adenomas correlated positively with basic serum GH level. These results are in accordance with the current hypothesis that ghrelin could have a direct autocrine or paracrine effect via GHSR, thereby promoting pituitary GH hormone synthesis and/or release.

In addition to stimulating hormone secretion, ghrelin, through its paracrine function, is believed to play an important role in processes associated with tumor progression; however, the molecular mechanisms are poorly understood $(19,20)$. Previous studies have investigated the effect of ghrelin on breast, ovarian and gastric cancer cell lines, although contradictory results were generated (21-23). An anti-proliferation effect has been documented in certain studies $(24,25)$, whereas others have described a potential tumor-promoting role of ghrelin $(26,27)$. It should be taken into consideration, however, that the use of cell lines and administered dose of ghrelin in these studies may 
not be representative of physiological conditions, underlying the necessity for further in vivo studies to be conducted.

In the present study, it was confirmed that ghrelin expression was associated with $\mathrm{GH}$ adenoma invasiveness, which is in line with the negative correlation with tumor diameter. This finding may suggest that ghrelin contributes to the development of $\mathrm{GH}$ adenomas mainly by promoting adenoma cell invasion, but not proliferation.

In conclusion, the present study found that ghrelin and GHSR expression, at both the mRNA and protein levels, was correlated with certain clinical features. The results showed that the expression levels varied among the different adenoma subtypes, with the highest mean level in GH adenomas, a moderate level in NF adenomas and the lowest level in ACTH adenomas. The ghrelin mRNA expression level in GH adenomas correlated positively with the basic serum GH level, but negatively with tumor diameter. Furthermore, the ghrelin mRNA expression levels in invasive $\mathrm{GH}$ adenomas were significantly higher than those in noninvasive $\mathrm{GH}$ adenomas. The present findings suggest that the binding of ghrelin to GHSR promotes $\mathrm{GH}$ hormone secretion and has an important role in the development of $\mathrm{GH}$ adenomas via an autocrine and/or paracrine action.

\section{Acknowledgements}

The current study was partially supported by the National Natural Science Foundation of China (grant no. 81101620) and the Clinical Project of the Wuhan Health Bureau (grant no. WX14B08). The authors would like to thank Miss Shunying Liu for her support in this study.

\section{References}

1. Chopin L, Walpole C, Seim I, et al: Ghrelin and cancer. Mol Cell Endocrinol 340: 65-69, 2011.

2. Honda K, Bailey AR, Bull PM, Macdonald LP, Dickson SL and Leng G: An electrophysiological and morphological investigation of the projections of growth hormone-releasing peptide-6-responsive neurons in the rat arcuate nucleus to the median eminence and to the paraventricular nucleus. Neuroscience 90: 875-883, 1999.

3. Kim K, Arai K, Sanno N, Osamura RY, Teramoto A and Shibasaki T: Ghrelin and growth hormone $(\mathrm{GH})$ secretagogue receptor (GHSR) mRNA expression in human pituitary adenomas. Clin Endocrinol 54: 759-768, 2001.

4. Howard AD, Feighner SD, Cully DF, et al: A receptor in pituitary and hypothalamus that functions in growth hormone release. Science 273: 974-977, 1996.

5. Chu S and Schubert ML: Gastric secretion. Curr Opin Gastroenterol 29: 636-641, 2013.

6. Skinner MM, Nass R, Lopes B, Laws ER and Thorner MO: Growth hormone secretagogue receptor expression in human pituitary tumors. J Clin Endocrinol Metab 83: 4314-4320, 1998

7. Korbonits M, Bustin SA, Kojima M, et al: The expression of the growth hormone secretagogue receptor ligand ghrelin in normal and abnormal human pituitary and other neuroendocrine tumors. J Clin Endocrinol Metab 86: 881-887, 2001.
8. Kim K, Sanno N, Arai K, et al: Ghrelin mRNA and GH secretagogue receptor mRNA in human GH-producing pituitary adenomas is affected by mutations in the alpha subunit of G protein. Clin Endocrinol (Oxf) 59: 630-636, 2003.

9. Knosp E, Steiner E, Kitz K and Matula C: Pituitary adenomas with invasion of the cavernous sinus space: a magnetic resonance imaging classification compared with surgical findings. Neurosurgery 33: 610-617, 1993.

10. Korbonits M, Kojima M, Kangawa K and Grossman AB: Presence of ghrelin in normal and adenomatous human pituitary. Endocrine 14: 101-104, 2001.

11. Stevanović D, Milosević V, Starcević VP and Severs WB: The effect of centrally administered ghrelin on pituitary ACTH cells and circulating ACTH and corticosterone in rats. Life Sci 80: 867-872, 2007.

12. Pecori Giraldi F, Bucciarelli LG, Saccani A, et al: Ghrelin stimulates adrenocorticotrophic hormone (ACTH) secretion by human ACTH-secreting pituitary adenomas in vitro. J Neuroendocrinology 19: 208-212, 2007.

13. Rau TT, Sonst A, Rogler A, et al: Gastrin mediated down regulation of ghrelin and its pathophysiological role in atrophic gastritis. J Physiol Pharmacol 64: 719-725, 2013.

14. Bowers CY, Momany FA, Reynolds GA and Hong A: On the in vitro and in vivo activity of a new synthetic hexapeptide that acts on the pituitary to specifically release growth hormone. Endocrinology 114: 1537-1545, 1984.

15. Korbonits $\mathrm{M}$ and Grossman AB: Growth hormone-releasing peptide and its analogues Novel stimuli to growth hormone release. Trends Endocrinol Metab 6: 43-49, 1995.

16. Smith RG, Van der Ploeg LH, Howard AD, et al: Peptidomimetic regulation of growth hormone secretion. Endocr Rev 18: 621-645, 1997.

17. Rotondo F, Cusimano M, Scheithauer BW, Rotondo A, Syro LV and Kovacs K: Ghrelin immunoexpression in pituitary adenomas. Pituitary 14: 318-322, 2011.

18. Rak-Mardyla A: Ghrelin role in hypothalamus-pituitary-ovarian axis. J Physiol Pharmacol 64: 695-704, 2013.

19. Nanzer AM, Khalaf S, Mozid AM, et al: Ghrelin exerts a proliferative effect on a rat pituitary somatotroph cell line via the mitogen-activated protein kinase pathway. Eur J Endocrinol 151: 233-240, 2004.

20. Avau B, De Smet B, Thijs T, et al: Ghrelin is involved in the paracrine communication between neurons and glial cells. Neurogastroenterol Motil 25: e599-608, 2013.

21. Yu H, Xu G and Fan X: The effect of ghrelin on cell proliferation in small intestinal IEC-6 cells. Biomed Pharmacother 67: 235-239, 2013.

22. Tian C,Zhang L,Hu D and Ji J: Ghrelin induces gastric cancer cell proliferation, migration, and invasion through GHS-R/NF- $\kappa \mathrm{B}$ signaling pathway. Mol Cell Biochem 382: 163-172, 2013.

23. Tian C, Ye F, Wang L, et al: Nitric oxide inhibits ghrelin-induced cell proliferation and ERK1/2 activation in GH3 cells. Endocrine 38: 412-416, 2010.

24. Cassoni $\mathrm{P}$, Papotti M, Ghè $\mathrm{C}$, et al: Identification, characterization, and biological activity of specific receptors for natural (ghrelin) and synthetic growth hormone secretagogues and analogs in human breast carcinomas and cell lines. J Clin Endocrinol Metab 86: 1738-1745, 2001.

25. Xu Y, Pang X, Dong M, Wen F and Zhang Y: Ghrelin inhibits ovarian epithelial carcinoma cell proliferation in vitro. Oncol Rep 30: 2063-2070, 2013.

26. Jeffery PL, Murray RE, Yeh AH, et al: Expression and function of the ghrelin axis, including a novel preproghrelin isoform, in human breast cancer tissues and cell lines. Endocr Relat Cancer 12: 839-850, 2005.

27. Grönberg M, Fjällskog ML, Jirström K and Janson ET: Expression of ghrelin is correlated to a favorable outcome in invasive breast cancer. Acta Oncol 51: 386-393, 2012. 